\title{
The Implementation of Local Culture on the Development of Reception Orale Teaching Materials through YouTube Media
}

\author{
Nurilam Harianja $^{1}$, Hesti Fibriasari ${ }^{2}$, T. Ratna Soraya ${ }^{3}$ \\ 1,2,3 Universitas Negeri Medan, Indonesia \\ Email: nurilam@unimed.ac.id
}

\begin{abstract}
:
The development of receptional orale teaching materials based on local culture through YouTube aims to help learners understand French language with the situation of local culture. The development of teaching materials using YouTube which is implemented in learning is very important to improve listening skills by French language learners. Besides this local culture-based video uploaded on YouTube will be very useful for French tourists visiting Indonesia, especially Medan. Therefore this video will present the real situation in Medan, for example, when making a reservation through the application for transportation or for others. The research method uses Research and Development that will be implemented in the French Language Education Study Program by developing teaching materials based on local culture to improve listening skills by Unimed French language students.
\end{abstract}

Keywords:

development of teaching materials, reception orale, YouTube, French language

\section{Introduction}

Education Law No. 20 of 2003 concerning the National Education System states about the basis, functions and objectives of national education based on Pancasila and 1945 Constitution of the Republic of Indonesia. It has the function of developing capabilities and shaping the dignified character and civilization of the nation in order to educate life nation, aims to develop the potential of students to become human beings who believe in and fear God Almighty, have noble, healthy, knowledgeable, capable, creative, independent, and become democratic and responsible citizens. This means that education must have a synergy between educators and students supported by learning tools. Learning tools in Higher Education include Semester Learning Plan and Learning Implementation Plan. Learning devices are equipped by learning media in the teaching and learning process. Learning media adapted to teaching materials that will be delivered to students. Therefore, the preparation of teaching materials tailored to the development of science that will later have relevance to the world of work of graduates.

French language teaching materials are currently developing and many have relevance to the development of Information and communication technology (ICT). Technology and information is currently provided for foreign language learners, namely the existence of platforms that are provided free of charge by the French government such as TV5 Monde, RFI, Bonjour de France and many others. The platform requires lecturers and students to be more creative to realize the educational industry revolution 4.0. The industrial revolution 4.0 has the characteristics of the first lecturer as a team leader who collaborates with students to create science and technology supported by various learning resources from the internet. Both learning materials according to practice needs are sourced from the internet. Third, the open learning process to enhance learner's creativity, build social networks across classrooms and scientific disciplines, adaptive learning that is controlled by many Artificial Intelligence Portals (internet based). Fourth, learning is no longer dependent on physical buildings because 
learning activities are carried out openly with lecturers exchanging across regions in national scope such as offering degrees and double degrees, and accreditation from many internationally recognized institutions. Fifth, students have the autonomy to prepare learning plans that are assisted by lecturers as advisors and supported by Artificial Intelligence Portals, where these learning plans can be updated continuously through adaptive mechanisms. Sixth, the E-learning management system is carried out in an integrated manner with many Artificial Intelligence applications.

The usage of Information and communication technology (ICT) in education is very broad, teaching and learning process becomes more creative and does not use the same teaching materials. The use of ICTs makes teaching materials more varied and develops in accordance with the times. Foreign language learning is currently created with infinite reach so that the learning process is not always in the classroom but can be done anywhere and anytime. This situation is used by teachers by creating creative ideas to create learning materials by utilizing ICT that can add to the treasury of foreign language learning. Foreign language instructors strive to create teaching materials based on local culture by using ICT as an effort to improve the ability of French language learners in reading, writing, speaking and listening competencies.

The usage of YouTube is one way to improve listening skills in French. Based on previous research Harianja (2018) about making French learning media in production orale subjects using YouTube stated that the application of learning media using YouTube is very possible to be used in learning to speak in French. Therefore, further studies will be conducted on the development of local culture-based teaching materials to improve listening skills using YouTube. This research is very important to do because the usefulness of the results of his research can later be utilized by French language learners and French tourists who travel to Medan.

When students make YouTube making process, the learner will find problems such as the recording does not produce clear sound, images are not good and taking positions when shooting. The process also trains students to be able to make teaching materials based on local culture. The situation and atmosphere of the location reflecting the culture in Indonesia is certainly different from the situation in France. Therefore it is very important to make teaching materials based on local culture. The development of this teaching material aims to help learners understand French with the local cultural situation that is used to improve listening skills using YouTube. One example of making teaching material about the Grab application using YouTube, as below:

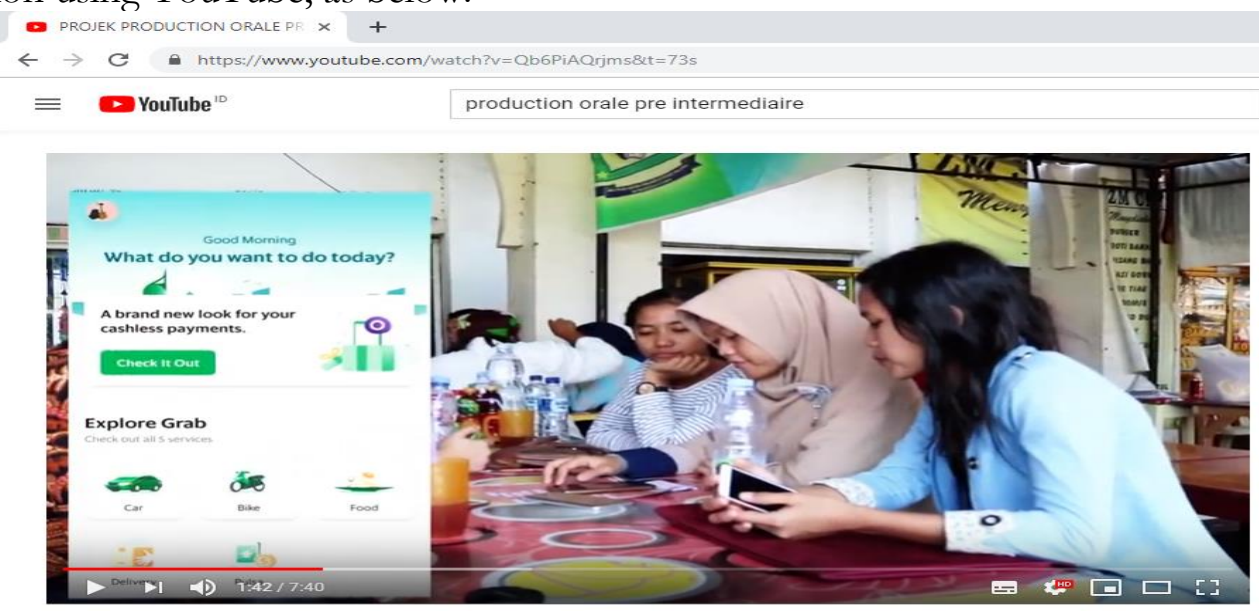

PROJEK PRODUCTION ORALE PRE INTERMEDIAIRE

Figure 1. YouTube learning of French Language 
Figure 1 is a student project in learning French that is carried out by a team of students in a production orale course. They determine the team and theme to be assigned to the project, after which they discuss to plan scenarios, locations, transportation, and all technical implementation. The results of the project were presented in French and uploaded to YouTube. The video can be used as teaching material for learning French. Students will more easily understand and be able to master French, this is because the video is set and created using Indonesian culture. Therefore the development of listening teaching materials using YouTube based on local culture is very important to improve the ability of French language learners. This video will also be very useful for French tourists visiting Indonesia, especially Medan, because this video will present the real situation in Medan for example when going to travel using public transportation.

\section{Review of Literature}

Local culture-based teaching materials to improve listening skills using YouTube will help French learners to understand French both verbally and in writing.

\subsection{The Development of Teaching Materials}

One of the important supporters in learning is teaching material. Effiong et al (2015) research results state that teaching materials used by students can improve learning outcomes. Ifeoma (2013) successfully stated that teaching materials are a set of materials and resources that help teachers and students in learning. Whereas Mudlofir (2012) argues that teaching materials are a set of materials arranged in a hierarchy in the form of both written and unwritten materials that can be used in the learning process. Teaching material is one of the important parts in the learning process. Teaching materials should be designed and written according to the rules of learning, i.e. adapted to learning materials, arranged based on learning needs, there are evaluation materials, and the instructional materials are interesting for students to learn (Widiastuti, et al: 2019).

Based on the opinion above that teaching material is a set of material that can improve student learning outcomes. Purwanto (2001: 5) states that the principles of teaching materials are a) arousing student interest in learning, b) explaining instructional objectives, c) using a good structure in presenting material, d) providing opportunities to practice and feedback to students, e) explain things that are considered difficult for students, f) create two-way communication. The development of teaching materials in this research is expected to assist students in increasing student interest in learning and learning outcomes. Teaching materials consist of printed and non-printed teaching materials, Majid (2009) divides 4 types of teaching materials including (a) printed teaching materials, (b) hearing materials (Audio), (c) teaching and viewing materials (audio visual) and, (4) interactive teaching materials.

\subsection{Local Culture}

Local wisdom is according to Wibowo and Gunawan (2015) that culture is the philosophy of education, while education is the main guardian of culture, because the role of education shapes people into a culture. The nation's character in students so that they have values and apply these values in their lives so that they become members of society and citizens who are religious, nationalist, productive and creative. At present, various regions in Indonesia are faced with the threat of local culture by modernization. Local culture which generally bears the traditional nature often makes it unable to survive in the rapids of the current modernization. Worse, there is the view of the community who assume that local wisdom is a primitive culture, thus making people allergic to it. Such views will certainly speed 
up the extinction of local culture which is actually a condition of value. Therefore, efforts to preserve local culture need designed and implemented in various forms, one of which is by integrating them into learning activities in schools. According to Latif (in Wibowo and Gunawan: 2015) character education should be based on one's own culture, in the form of excavation of noble values that exist in local wisdom. As we know, every region in Indonesia has local wisdom. Then the character values internalized through characters should be taken through the noble values of each local culture. Exploration of local wisdom values as a basis for character education is also in line with UNESCO's recommendation in 2009. According to UNESCO, exploring local wisdom as a basis for character education and education in general, will encourage the emergence of mutual respect between ethnic, ethnic, national, and religion, so diversity is maintained.

\subsection{Reception Orale}

French language learning has four competencies, one of which is listening competency. These competencies are presented in reception orale courses. As for measuring achievement in listening capacity, students have the ability to listen, choose, summarize and create audiovisual texts. They will be able to explain and compare elements of French so that they acquire the skills and knowledge needed for listening skills, so as to improve students' listening skills. According to Darti and her friends (2017: 221) listening is an important part of English as foreign language. This is similar to other skills such as writing, reading and speaking. Listening is a very important skill because it is the most widely used technique every day. According to Juvrianto (2018: 1), "Listening is the ability in which humans use their sense of hearing to understand and understand what a speaker means. That is, that listening is a capacity, when human use has his sense of hearing to listen and understand what a speaker means.

According to Arono (2014: 63) "Listening skills are a process in language skills that need to be practiced using audio / technology like the research conducted". That is, listening skills are skills that must be created using audio/technology, such as research conducted. Based on the findings above, listening skills are one of the skills that require tools such as audio or technology to understand what audio means.

\subsection{YouTube}

The usage of Information and communication technology (ICT)-based learning media is very helpful for learners to learn foreign languages online. Learning media such as blogs, elearning and YouTube. The use of ICT-based learning media is very helpful for learners to learn foreign languages online. Learning media such as blogs, e-learning and YouTube. Along with the times that make competition in terms of information technology. Youtube comes with all the conveniences provided. YouTube is a website in the form of a popular video sharing service that allows users to load, watch and share video clips for free. Since it was launched in December 2005 and acquired by Google in 2006, YouTube users have continued to increase to more than one billion per day (Wall Street Journal, 9 July 2008 in Burnett, Melissa, 2008). The latest statistics show that more than 4 billion YouTube videos are watched every day. This media is very popular because it can function as a source of information, entertainment and self-expression that can be accessed widely in 24 hours in 39 countries in 54 languages. In 2011, YouTube views reached more than 1 trillion or almost 140 views for every person on earth. (www.YouTube.com). According to Agazio \& Bucklev (2008), YouTube is a web-based file sharing service that allows individuals to build public profiles, determine the list of other users to share videos and to see a list of connections / content made by others. 


\subsection{French Language}

Teaching and learning process with a two-way communication between instructors and learners by using instructional devices. Learning tools in the form of teaching materials, media, models and methods become facilitators to deliver messages or learning material. Learning material delivered to learners is greatly influenced by the ability of learners with the existence of learning resources that can make students learn independently according to the visual, auditory and kinesthetic abilities possessed by the learner. According to Nursalam (2008) in a statement that the determination of the selection of the right method should consider the right aspects should consider the aspects to be achieved, namely referring to the outline of the learning program which is divided into two types:

1. The learning process is able to encourage students to organize and fill new experiences based on the past that has been experienced. Example: question and answer exercises, interviews, consultations, sensitivity exercises etc.

2. The learning process is designed to increase the transfer of new knowledge, new experiences, and new skills so that they can encourage each of them to achieve as much as possible the knowledge they want, what they need, and the skills needed. Example: learning to use a computer.

The usage of Information and communication technology (ICT)-based learning media is very helpful for learners to learn foreign languages online. Learning media such as blogs, elearning and YouTube.

Along with the times that make competition in terms of information technology. YouTube comes with all the conveniences provided. YouTube is a website in the form of a popular video sharing service that allows users to load, watch and share video clips for free. Since it was launched in December 2005 and acquired by Google in 2006, YouTube users have continued to increase to more than one billion per day (Wall Street Journal, 9 July 2008 in Burnett, Melissa, 2008). The latest statistics show that more than 4 billion YouTube videos are watched every day. This media is very popular because it can function as a source of information, entertainment and self-expression that can be accessed widely in 24 hours in 39 countries in 54 languages. In 2011, YouTube views reached more than 1 trillion or almost 140 views for every person on earth. (www.YouTube.com). According to Agazio \& Bucklev (2008), YouTube is a web-based file sharing service that allows individuals to build public profiles, determine the list of other users to share videos and to see a list of connections / content made by others .

\subsection{Previous Research}

Information and communication technology-based learning media is very helpful in the process of learning French because of the availability of PRAAT software to improve the speaking ability of French students in the Audition Pronunciation course in order to have articulation that approaches the native speaker (Fibriasari \& Irwandy, 2015). To see the mistakes that are often made by students when connecting the word liaison when reading text. Improving the ability of Unimed French students to read properly and correctly in accordance with applicable rules. Unimed French Study Program presents the Comprehension écrite I course at the beginning of the semester and is adjusted to the DELF A1 European standard (CECR) curriculum (Harianja and Fibriasari: 2015). The use of Information Technology and Computers in learning aims to improve vocabulary mastery. By using the TV5Monde website it is hoped that learners will find it easier to learn French vocabulary (Harianja and Fibriasari, 2017). Making French Learning Media in Production Orale Subjects Using YouTube (Harianja et al, 2018). 


\section{Research Method}

This research uses an R\&D (Research and Development) approach. R\&D research is a basic research activity to obtain information on user needs (needs assessment), then continued development activities to produce products and test the effectiveness of these products. In this study using the R\&D approach because in this study will produce products in the form of interactive learning media Static Promotion subjects. Borg and Gall revealed that there are 10 steps in the development research process, but in the Puslitjaknov Team (2008: 11), development research procedures according to Borg and Gall can be done more simply involving 5 main steps, namely: (1) Conducting an analysis of products to be developed; (2) Developing initial products; (3) Expert validation and revision; (4) Small-scale field trials and product revisions; (5) Large-scale field trials and final products. The steps in the development procedure can be described as follows:

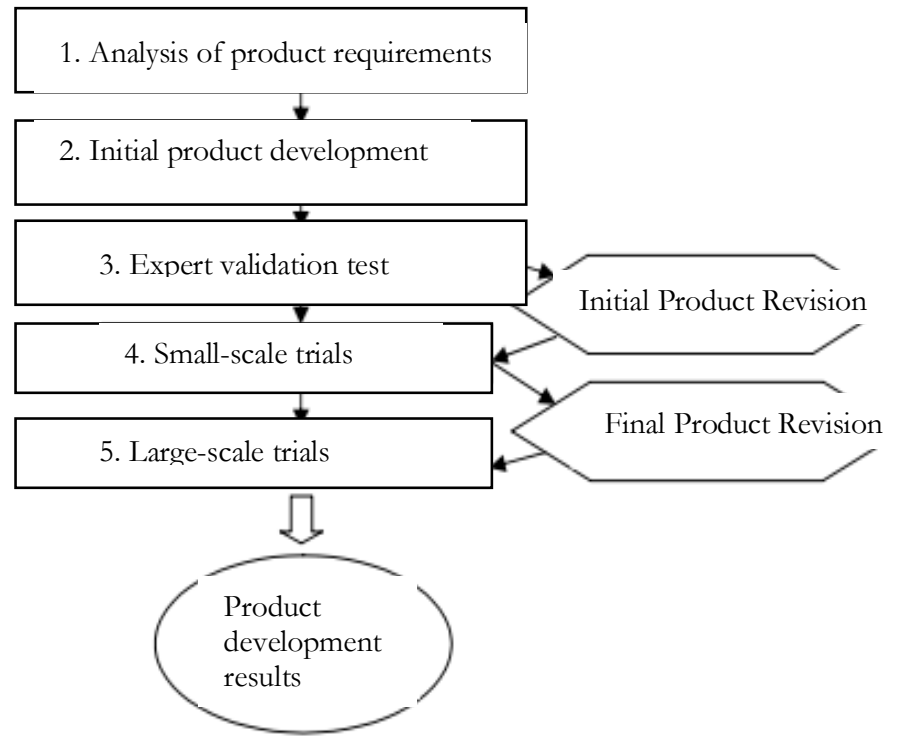

Figure 1. Development Research Procedure

The research was carried out at Unimed French Language Education Study Program. The research time was conducted in June-November 2019. The research subjects in this research development consisted of 2 media experts, 2 material experts, 23 students on small and large scale field trials. Data collection techniques used in this study were observation, interviews and questionnaires. Observations are made when the research will be carried out to obtain data as a basis for the implementation of research and development. Interviews were conducted with listening lecturers and students to obtain data on needs in research and development. The questionnaire was used to obtain quality assessment data for media feasibility developed according to media experts, as well as a questionnaire to obtain quality assessment data from material experts, as well as students on small-scale field trials.

\section{Discussion}

\subsection{Data Collection}

In this step, a preliminary study was conducted using the documentation method to find out what material was available for semester 1. Data obtained included material contained in semester 1. For the analysis of needs, the questionnaire and interview methods were used. The needs analysis questionnaire was distributed to Unimed French students. Short interviews were conducted with a French courses who taught expression orale courses at the Unimed French Study Program. This is intended to obtain information about the needs of lecturers 
and students for the semester 1 French learning video media on listening skills.

\subsection{Product Design}

In this step, it starts with designing the appropriate material that will be included in the reception orale learning video then designs the product to be made, namely the the learning video of expression orale French language semester 1. At this stage the researcher makes a synopsis, production script and scenario. After that proceed with the process of shooting and editing video. Then process the video and graphics into French orale reception learning display.

\subsection{Validation}

At the validation stage, a French linguist is chosen who is considered capable of knowing the suitability of the product design that has been made. This is done to find out the weaknesses and weaknesses. According to Sugiyono (2010: 414) design validation is an activity process to assess whether product design, in this case a new work system will be rationally more effective than the old one or not. From the above opinion it was concluded that the educational products developed must go through an assessment process before being implemented in the field. In addition, product validation can be done by presenting several experienced experts to assess the new product that is designed. In validating a product according to Sugiyono (2010: 414) each expert was asked to rate the design, so that further weaknesses and strengths could be known. To test the tool, a validation sheet is created which will be used to test the product. This validation test sheet can help find out the media model that was made. This validation sheet contains aspects of the French learning media video of the 1st semester Reseption Orale course on listening skills. This validation test sheet is filled in by expert lecturers. In addition to providing corrections, the expert lecturer is also expected to provide input and suggestions for improving the listening evaluation tools that have been made. So the products produced have better quality and feasibility than before.

\subsection{Small Scale Trials and Design Revisions}

To find out the weaknesses and shortcomings of the product, a small-scale trial was conducted. From the results of the small-scale trial, 4 students $(17.40 \%)$ obtained the A results, 9 students $(39.13 \%)$ obtained the B results, 10 students $(43.47) \%)$ get a score of C. The results obtained make researchers less satisfied with the product design results that have been designed. Thus a revision of the product is needed by the design expert.

After knowing the weaknesses and some input from the media experts, the researcher made a revision of the design according to the advice of the experts, so as to produce a design that was ready to be implemented.

\subsection{Large Scale Field Trials}

After the developed product is revised, a large-scale trial is carried out again using local culture-based learning videos for listening skills. The results of large-scale trials obtained 8 students $(34.80 \%)$ get a score of A, 9 students $(39.10 \%)$ get a score of B, and 6 students $(26.10 \%)$ get a score of C. 


\section{Conclusion}

Based on the results of research and product development carried out researchers, can be concluded as follows:

1. Based on the analysis of needs through a questionnaire for students and interviews with French language lecturers, it can be seen that video media learning in French language for the 1 st semester is needed as a listening learning media. The required videos were short videos and based on local culture.

2. The results of this research and media development are learning videos listening to French for semester 1 based on local culture that lasts four to five minutes can improve the ability to listen to French students.

3. The results of the trial conducted by applying the learning media in the form of local culture-based videos using YouTube have a good impact in increasing the ability to listen to French students.

\section{References}

Agazio, J. \& Buckley, K. (2008). An untapped resource: Using YouTube in nursing education. Nurse Educator, 34(1), 23-28.

Arono. 2014. Improving Students Listening Skill through Interactive Multimedia in Indonesia. Journal of Language Teaching and Research, Vol. 5, No. 1, pp. 63-69, January

Arsyad, Azhar. 2009. Media Pembelajaran. Jakarta: Rajawali pers

Darti, Asmawati, Andi. 2017. Analyzing Students'DIificulties to ward Listening Comprehension. JurnalComprehension of English Education Department of Tarbiyah and Teaching Faculty at UIN Alauddin Makassar. Volume 3, Number 02 December

Dick, W., Carey, L., \& Carey, J. O. (2001). The systematic design of instruction (5th ed.). New York: Addison-Wesley Educational Publisher Inc.

Effiong., Ekpo, O., \& Charles, I. E. (2015). Impact of instructional materials in teaching and learning of bilogy in senior secondary schools in Yakurr LG A. International Letters of Social and Humanistic Science, 62, 27-33.

Fibriasari, H. 2015. The Audition Prononciation Learning Based on Multimedia in French Section of Unimed. Proceeding on Edicational Creativity and Innovation in Prespectives of The ASEAN-China Relations. 5-6 November.2015, Kang Ming Hotel, Beijing. Hal. 299-307.

Fibriasari, H. 2016. Perfectionnement du modèle d'apprentissage de l'audition prononciation. Proceeding on Conference International Sur Le Français "Le Français: en jeux linguistique, politique, economique et la culture. 3 Novembre 2016. UPI. Bandung.

Fibriasari, H. 2016. Prosodic Frequency in Signaling Linguistic Distinctions at UNIMED First Year Non-native French Students. International Journal of Humanities and Social Science Vol. 6, No. 10; October 2016. Hal 118-124.

Harianja, N. 2019. Youtube as the Learning Media to Improve the Speaking Skill in Expression Orale Course.Asian Themes in Social Sciences Research ISSN: 2578-5516 Vol. 3, No. 1, pp. 14-17 2019 DOI: 10.33094/journal.139.2019.31.14.17

Ifeoma, M. M. (2013). Use of instructional materials and education performance of student in integrated science (a case study of Unity Schools in Jalingo, Taraba state, Nigeria). IOSR Journal of Research \& Method in Education (IOSRJRME), 3(4), 07-11.

Juvrianto, Atmowardoyo, Weda. 2018. The Use of Digital Storytelling in Teaching Listening Comprehension: An Experimental Study on the Eighth Grade Students of SMP Negeri 4 Parepare . Jurnal ELT Worldwide Vol. 5 No. 1 
Majid, A. (2009). Perencanaan pembelajaran mengembangkan kompetensi guru. Bandung: PT Remaja Rosdakarya.

Mudlofir, A. (2011). Aplikasi pengembangan KTSP dan bahan ajar dalam pendidikan agama Islam. Jakarta: PT RajaGrafindo Persada.

Purwanto, P.P. (2001). Penulisan bahan ajar. Jakarta: PAU-PPAI, Universitas Terbuka.

Siswadi, Taruna, T., \& Purnaweni, H. (2011). Kearifan lokal dalam melestarikan mata air (studi kasus di desa purwogondo, kecamatan boja, kabupaten Kendal). Junal Ilmu Lingkungan, Vol. 9, No. 2, Pg. 64

Unité des Politiques linguistiques, Cadre européen commun de référence. Strasbourg www.coe.int/lang-CECR

Wibowo, Agus \& Gunawan. 2015. Pendidikan Karakter Berbasis Kearifan Lokal di Sekolah. Yogyakarta: Pustaka Pelaja

Widiastuti, U. et al. (2019). Development of Traditional Harmony-Based Teaching Materials Based on HOTS to Improve Student Musicality of Music Education Program at Language and Art Faculty at State University of Medan (UNIMED). Budapest International Research in Linguistics and Education Sciences (BirLE), 227-238.

Widodo, C.S. \& Jasmadi. (2008). Panduan menyusun bahan ajar berbasis kompetensi. Jakarta: PT Elex Media Komputindo. 